\title{
UPAYA PENINGKATAN PEMAHAMANKENDALI DIRI MELALUI \\ LAYANAN ORIENTASIBAGI PESERTA DIDIK KELAS IX-F SMP NEGERI 8 PAMEKASAN
}

\author{
Drs. Agus Supriadi, M.Pd. \\ Guru BK SMPN 8 Pamekasan, Jl. Jalmak 43 A Pamekasan \\ E-mail : abahagus65@gmail.com
}

\begin{abstract}
ABSTRAK
Permasalahan dalam penelitian ini adalah masih banyaknya peserta didik yang belum memahami tentang kendali diri (sebagaimana diperoleh dari Hasil Identifikasi Kesulitan dan Masalah Siswa yang mencapai83,9\%).Tujuan dari penelitian ini yakni upaya untuk meningkatkan pemahaman kendali diri bagi peserta didik kelas IX-F SMP Negeri 8 Pamekasan melalui layanan orientasi. Penelitian ini menggunakan rancangan penelitian tindakan kelas (PTK) sebanyak 2 siklus, hasil siklus I adalah94,95 $\%$ atau mengalami penurunan permasalahan sebesar 11,05\% dibandingkan dengan hasil asessement (sebelum pelaksanaan layanan orientasi). Dan pada siklus II mengalami peningkatan pemahaman peserta didik tentang kendali diri sebesar 98,99\% yang berarti mengalami penurunan sebesar 15,09\% dari hasil asessement. Berarti dari siklus I ke siklus II mengalami peningkatan pemahaman kendali diri yang dihadapi peserta didik sebesar 4,04\%.Berdasarkan hasil penelitian, maka dapat disimpulkan bahwa dengan melalui Layanan Orientasi dapat meningkatkan pemahaman kendali diri peserta didik Kelas IX-F SMP Negeri 8 Pamekasan.
\end{abstract}

Keyword : Peserta Didik, Orientasi.

\section{PENDAHULUAN}

Layanan Bimbingan dan Konseling yang diberikan di sekolah pada intinya suatu bentuk pemberian bantuan kepada peserta didik untuk dapat memecahkan permasalahan yang dihadapinya. Dari hasil asessement menunjukkan bahwa peserta didik kelas IX-F memilik permasalahan tentang pemahaman kendali diri, seperti halnya pada grafik berikut:

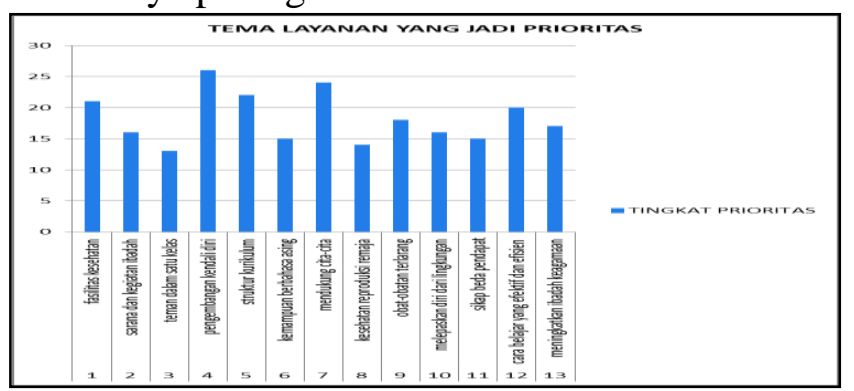

Gambar 1Grafik tema layanan hasil assessment yang menjadiprioritas

JURNAL IKA VOL 7 No. 1 JUNI 2019 | 57
Dalam layanan orientasi, selain tujuan yang hendak dicapai ada beberapa fungsi yang harus diperhatikan. Sedangkan fungsi utama bimbingan konseling yang didukung oleh layanan orientasi adalah: pemahaman, pencegahan, pengentasan, pemeliharaan dan pengembangan, serta advokasi. Fungsi ini diselengarakan dalam kegiatan layanan Bimbingan dan Konseling tergantung dari program yang dibutuhkan oleh peserta didik atau konseli. Fungsi Bimbingan dan Konseling pada dasarnya memberikan rasa memahami, aman, nyaman, dan sebagainya kepada peserta didik yang membutuhkan layanan tersebut.Seperti yang dikemukakan oleh Gerald Corey dalam buku Teori dan 
Praktek Konseling \& Psikoterapi (2005: 118): "bahwa individu memiliki kesanggupan memikul tanggung jawab pribadi dan hidup sepenuhnya sebagai pribadi yang terpadu.

Untuk memecahkan masalah di atas, khususnya pemahaman yang berkaitan dengan kendali diri, maka peneliti dalam layanan Bimbingan dan Konseling melaksanakan kegiatan jenis orientasi. Jenis layanan orientasi sebagaimana yang sering digunakan di lapangan ini adalah salah satu kegiatan dalam Layanan Bimbingan dan Konseling yang dilaksanakan secara klasikal dengan waktu yang terjadwal. Rumusan masalah yang dapat peneliti sajikan adalah "Apakah upaya pemahaman kendali diri dapat ditingkatkan melalui layanan orientasi bagi peserta didik kelas IX-F SMP Negeri 8 Pamekasan"

$$
\text { Adapun tujuandan manfaat }
$$
daripenilianiniyakni: memperoleh gambaran peningkatan pemahaman kendali diri peserta didik melalui pelaksanaan layanan orientasi serta dapat dengan segera menuntaskan permasalahan yang dihadapi yang berkaitan dengan pemahaman kendali. Dan pengertian layanan orientasi menurut Faza, dkk (2012:1) adalah: "suatu kegiatan yang memungkinkan peserta didik dapat memahami dan menyesuaikan diri dengan lingkungan baru terutama lingkungan sekolah". Nurhuda Agus (2013:1) JURNAL VOL 7 NO. 1 JUNI 2019| 58 menyatakan layanan orientasi secara umum adalah layanan bimbingan yang dikoordinir guru pembimbing dengan bantuan semua guru dan wali kelas, dengan tujuan mengorientasi (mengarahkan, membantu, mengadaptasi) siswa.Jadilayananorientasiadalah salah satu layanan yang dapat disampaikan secara klasikal dalam kegiatan layanan Bimbingan dan Konseling, khususnya pada fungsi pemahaman yaitu membantu peserta didik untuk mengenal dan memahami diri dan lingkungannya secara total.Dalam penelitian ini, hasilyang ingin dilihat adalah peningkatan pemahaman tentang kendali diri yang dihadapi peserta didik melalui layanan orientasi.

\section{METODE}

Penelitian ini menggunakan model penelitian atau rancangan penelitian tindakan kelas (PTK) atau dalam Bimbingan dan Konseling lebih dikenal dengan Penelitian Tindakan Kelas dalam Bimbingan dan Konseling (PTBK), yang terdiri dari perencanaan, pelaksanaan tindakan, observasi dan refleksi, dan perbaikan perencanaan.Teknik pengumpulan data yang digunakan dalam penelitian ini terdiri atas dokumentasi dan evaluasi pelaksanaan layanan. Sumber data dokumen dalam penelitian ini dapat dilihat dari hasil asessement pada saat peserta didik awal tahun pelajaran. Dan dokumen hasil asessement ini dapat dijadikan bahan 
pemahaman dan permasalahan yang dihadapi peserta didik .Data yang telah terkumpul akan dianalisis secara deskriptif, yakni deskriptif kuantitaif. Data yang akan dianalisis secara kuantitaif adalah data hasil angket yang berupa pemahaman peserta didik tentang kendali diri yang dinyatakan dengan nilai (score) yang dicapai peserta didik yang diperoleh dari hasil evaluasi.

\section{HASIL PENELITIAN}

Dari hasil analisa data diketahui bahwa aspek yang menyangkut pemahaman kendali diri dari hasil asessement diketahui permasalahan yang dihadapi peserta didik kelas IX-F yang harus segera mendapat layanan Bimbingan dan Konseling sebesar 83,9 \%. Setelah dilaksanakan tindakan pada siklus I diperoleh hasil $94,95 \%$, hal ini dapat dikatakan bahwa tidak ada masalah tentang pemahaman kendali diri yang dihadapi peserta didik. Peserta didik merasa telah memahami perihal kendali diri melalui layanan orientasi yang telah dilaksanakan, hal ini ditunjukkan dengan tingkat penurunan permasalahan yang dihadapi peserta didik sebesar $11,05 \%$.

Dari hasil analisa data diketahui bahwa aspek yang menyangkut pemahaman kendali diri dari hasil asessement diketahui permasalahan yang dihadapi peserta didik kelas IX-F yang harus segera mendapat layanan Bimbingan JURNAL VOL 7 NO. 1 JUNI 2019| 59 dan Konseling sebesar 83,9 \%. Setelah dilaksanakan tindakan pada siklus II diperoleh hasil 98,99 \%, hal ini dapat dikatakan bahwa tidak ada masalah tentang pemahaman kendali diri yang dihadapi peserta didik. Peserta didik merasa telah memahami perihal kendali diri melalui layanan orientasi yang telah dilaksanakan, hal ini ditunjukkan dengan tingkat penurunan permasalahan yang dihadapi peserta didik sebesar 15,09 \%. Berdasarkan pengamatan dan analisis data karena sudah mengalami peningkatan pemahaman dari siklus I yakni sebesar $11,05 \%$ menjadi $15,09 \%$ pada siklus II, sehingga tidak perlu adanya perbaikan pada siklus selanjutnya.

\section{PEMBAHASAN}

Dengan pelaksanaan kegiatan layanan orientasi memberikan bantuan pemecahan masalah bagi peserta didik di kelas IX-F SMP Negeri 8 Pamekasan yang cukup tinggi. Hal ini dapat dilihat pada hasil penilaian yang dilakukan peneliti yakni dari hasil asessement permasalahan peserta didik yang dihadapi yang menyangkut pemahaman kendali diri mencapai 83,9\%. Setelah dilakukan tindakan, baik pada siklus I maupun siklus II diperoleh hasil penurunan permasalahan yang dihadapi peserta didik tentang pemahaman kendali diri, sebagaimana yang ditunjukkan pada grafik berikut: 


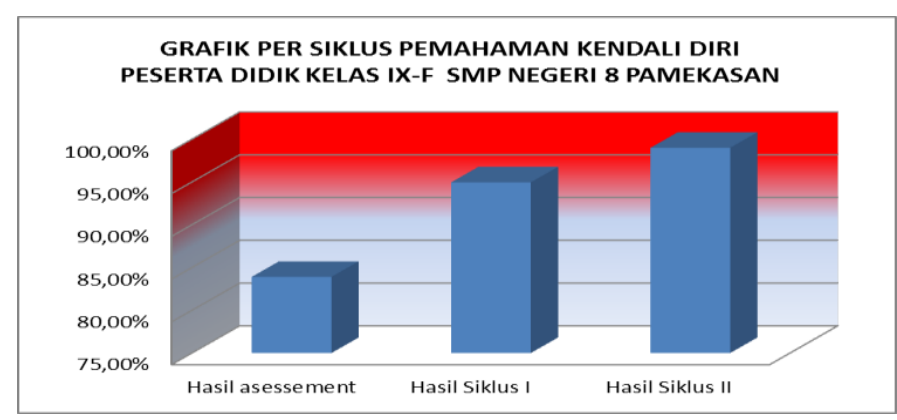

Pada tindakan siklus I diperoleh hasil 94,95 \%, yang berarti pada siklus I ini mengalami penurunan permasalahan pemahaman kendali peserta didik sebesar 11,05\%. Pada tindakan siklus II diperoleh hasil $98,99 \%$, hal ini membuktikan pula adanya penurunan permasalahan yang dihadapi peserta didik tentang pemahaman kendali diri sebesar 15,09 \%. Sehingga "Upaya Pemahaman Kendali Diri Melalui Layanan Orientasi bagi Peserta didik Kelas IX-F SMP Negeri 8 Pamekasan dapat ditingkatkan"

Pada siklus I ini hasil layanan belum maksimal maka perlu dilakukan tindakan perbaikan pada siklus II sebagai berikut : (1) konselor tidak mengkondisikan peserta didik sebelumnya, misalnya menanyankan kesehatan, masalah, atau hal-hal lain yang dimungkinkan untuk kondisi peserta didik sebelum pelaksanaan layanan, (2) konselor kurang memberikan kesempatan yang seluas-luasnya kepada peserta didik untuk tanya jawab dalam penyampaian materi layanan, (3) konselor dalam penyampaian materi kurang memberikan contoh konkrit yang berhubungan dengan kendali diri, (4) konselor tidak memberikan perhatian JURNAL VOL 7 NO. 1 JUNI 2019| 60 secara merata kepada peserta didik, sehingga ada sebagian peserta didik yang kurang memperhatikan penjelasan yang disampaikan, dan (5) waktu yang diberikan untuk penilaian kurang mencukupi, dan ada salah satu soal dalam penilaian yang belum dipahami peserta didik untuk menjawabnya.

Hasil observasi pada siklus II nampak adapeningkatan selama berlangsungnya kegiatan layanan yaitu:(1) konselor telah mengkondisikan peserta didik sebelumnya, misalnya menanyankan kesehatan, masalah, atau hal-hal lain yang dimungkinkan untuk kondisi peserta didik sebelum pelaksanaan layanan, (2) konselor memberikan kesempatan yang seluasluasnya kepada peserta didik untuk tanya jawab dalam penyampaian materi layanan, (3) konselor dalam penyampaian materi memberikan contoh konkrit yang berhubungan dengan kendali diri, (4) konselor memberikan perhatian secara merata kepada peserta didik, sehingga tidak ada lagi peserta didik yang kurang memperhatikan penjelasan yang disampaikan, dan (5) waktu yang diberikan untuk penilaian telah mencukupi, dan pemahaman dalam mengisi penilaian yang diberikan konselor.

\section{SIMPULAN}

Berdasarkan penelitian, maka dapat disimpulkan bahwa dengan melalui Layanan Orientasi dapat meningkatkan 
pemahaman kendali diri peserta didik Kelas IX-F SMP Negeri 8 Pamekasan. yang dibuktikan dengan meningkatnya hasil tindakan pada siklus I sebesar 94,95 $\%$ atau mengalami penurunan permasalahan sebesar 11,05\%. Dan pada siklus II mengalami peningkatan pemahaman peserta didik tentang kendali diri yakni sebesar 98,99 \% yang berarti mengalami penurunan sebesar 15,09\% dari hasil asessement. Sedangkan permasalahan yang dihadapi peserta didik dari hasil asessement mencapai hasil asessement sebesar 83,9 \%. Berarti dari siklus I ke siklus II mengalami peningkatan pemahaman kendali diri yang dihadapi peserta didik sebesar 4,04.

\section{DAFTAR RUJUKAN}

Adam Saputra, Muthoharoh, dan Aria Lantas. $2015 . \quad$ JenisJenisKegiatanLayananBimbingandan Konseling, (Online) (http://kumpulaninspirasi.blogspot.co .id , diakses 14 Agustus 2016)

Ahmad Abdullah, dkk. 2014.

LayananOrientasidanLayananInform asi, (Online)

(http://tarbiyahstaidarussalam.blogsp ot.com .diakses 13 Agustus 2016)

Alex Sobur. 2010. Psikologi Umum dalam Lintasan Sejarah. Bandung: Pustaka Setia

Calhoun, J.F. danAcocella, J.R. Alihbahasaoleh RS.Satmoko. 1995. PsikologitentangPenyesuaiandanHu bunganKemanusiaan. Semarang: IKIP Semarang Press.
Dahar, Ratna W. 1996. Teori-teori Belajar. Jakarta: Erlangga.

Faza, Firstalenda, Fitria E, Fitrya K. 2012, LayananOrientasi. (Online)

(http://fi3fa.blogspot.co.id/2012/05/1 ayanan-orientasi.html.diaksestanggal 7 Agustus 2016)

Gerald Corey. 2005.Teori dan Praktek Konseling \& Psikoterapi. Bandung: PT. Refika Aditama.

Kemmis, S. dan Mc. Taggart, R. 1990. The Action Research Planner. Victoria:Dearcin University Press.

LailatulUktafiyah, Rohmad Bilal Nugroho, danKhasantulLidayati. 2014. MakalahDasardasarBimbingandanKonseling "LayananOrientasidanInformasi", (Online). (http://khasanatullidayati.blogspot.co .id, diaksestanggal 14 Agustus 2016)

Logue, Alexandra W. 1995. Self-Control Waiting unti Tomorrow for What You Want Today. New Jersey: Prentice Hall.

NurhudaAgus. 2013. Layanan Orientasi. (Online)

(http://agusnurhuda82.blogspot.co.id. diakses tanggal 8 Agustus 2016)

Sukartini, Sri Patmah. 2003. Model KonselingKeterampilanHidupuntuk MengembangkanDimensiKendaliPri badi yang Tegar. DisertasiDoktorpada PPS UPI Bandung: tidakditerbitkan.

Undang-undang No 20 tahun 2003 tentang Sistem Pendidikan Nasional.

Woolfolk,Anita.2011.Educational PsychologyActive LearningEdition,EdisiKesepuluhBa gianPertama. Yogyakarta:PustakaPelajar 


\section{CURRICULUM VITAE}

Nama

Tempat/Tgl. lahir Agama

JenisKelamin

Unit Kerja

Alamat Unit Kerja

No. Telp.

Email

Blog

Mengajar

AlamatRumah

No. HP/WA

JabatanOrganisasi
: Drs. AGUS SUPRIADI, M.Pd.

: $\quad$ Pamekasan, 7 Agustus 1965

: Islam

: Laki-laki

: SMP Negeri 8 Pamerkasan

: Jl. Jalmak 43 - A Pamekasan 69351

: (0324) 327880

: abahagus65@gmail.com

: abah-agus@blogspot.com

: Guru BimbingandanKonseling

: Jl. P. Diponegoro I / 17 Pamekasan 69315

: 08179317635

: 1. KetuaMusyawarah Guru Bimbingandan Konseling SMP Kab. Pamekasan

2. KetuaKomunitas Guru Bimbingandan Konseling SMP Kab. Pamekasan

3. PengurusYayasanTakmir Masjid AgungAsySyuhada' KabupatenPamekasan 